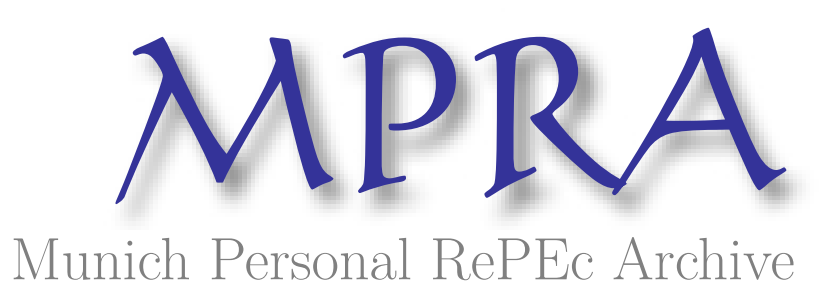

\title{
James M. Buchanan: Neoclassical, Austrian, Neither, or Both?
}

\author{
Durnin, Brian
}

City, University of London

28 September 2017

Online at https://mpra.ub.uni-muenchen.de/89629/

MPRA Paper No. 89629, posted 27 Oct 2018 07:36 UTC 


\title{
James M. Buchanan:
}

\section{Neoclassical, Austrian,}

\section{Neither, or Both?}

\author{
Brian P. Durnin \\ September 2017 \\ Dissertation submitted in partial fulfilment of the MSc in Economics \\ Department of Economics \\ City, University of London
}




\section{Introduction}

Four years after his passing, Nobel Laureate James M. Buchanan was back in the news. This past summer, a new book entitled Democracy in Chains: The Deep History of the Radical Right's Stealth Plan for America by Duke University history professor Nancy McLean, was published. It has been advertised as an "intellectual biography" of James Buchanan, though a cursory review of some interviews with the author reveals the book has more to do with political ideologies than with economics. The book's release has caused quite a bit of controversy from all parts of the political spectrum. One headline in The Washington Post read: "The beliefs of economist James Buchanan conflict with basic democratic norms. Here's Why" (Chwe, 2017) This was followed the following week with an article: "Was Nobel Laureate James Buchanan really opposed to democracy? Not at all." (Vanberg, 2017) There were many other examples from under every rock of the political spectrum. However, much of the disagreement was on Buchanan's supposed political ideology and agenda, not his economic theories. It should be quickly noted that Buchanan described himself as apolitical:

I resist, and resist strongly, any and all efforts to pull me toward positions of advising on this or that policy or cause. I sign no petitions, join no political organizations, advise no party, serve no lobbying effort. Yet the public's image of me, and especially as developed through the media after the Nobel Prize in 1986, is that of a right-wing libertarian zealot who is antidemocratic, anti-egalitarian, and antiscientific. I am, of course, none of these and am, indeed, the opposites. Properly understood, my position is both democratic and egalitarian, and I am as much a scientist as any of my peers in economics. But I am passionately individualistic, and my emphasis on individual liberty does set me apart from many of my academic colleagues whose mind-sets are mildly elitist and, hence, collectivist. (Buchanan, quoted in Formaini, 2003, p3)

Having dispensed of the emotionally overcharged ideological debates on defining Buchanan, a more interesting and vibrant discussion can be had from the history of economic thought perspective. Buchanan won the Nobel prize in 1986, primarily for his work on public choice theory, which he spearheaded with the 1962 book The Calculus of Consent, co-authored with Gordon Tullock. Another development in economics that Buchanan can claim as his own was the birth of the Virginia School of Political Economy. There is a 
plethora of papers claiming, to some degree or another, that Buchanan and these two subfields fall under the umbrella of the Austrian economic school. There are other historians, however, that point to links between Buchanan and the neoclassical approach, primarily through connections with the likes of George Stigler and Milton Friedman. There are still others that take a less binary view, claiming that Buchanan was a link or bridge between the two schools of thought, though some of the more devout economists from either school would quickly deny the possibility of such a construct.

I posit that, allowing for a slight amount of breathing room, James Buchanan's economic writings are more Austrian than anything else. From his earliest writings to his last publications, Buchanan clearly had an Austrian-leaning approach. Additionally, many of the criticisms he laid out about the economics profession were directed toward the more neoclassical minded amongst his peers. While the act of criticizing neoclassicals does not indicate that Buchanan was an Austrian, it does seem to lay to rest any conclusions that he was a neoclassical economist himself.

To prove Buchanan's Austrian leanings, I first attempt to define what it means to be an Austrian. As will be shown, there has been a modicum of debate on this issue, but there are some general points that the majority seem to agree with. I then show, through Buchanan's own writings as well as analyses by his peers, how Buchanan fits within each of the Austrian ideals. The next section consists of additional writings and statements by Buchanan that, while not specifically addressing any of the Austrian tenets, are still either pro-Austrian, anti-neoclassical, or both. I also present a selection of alternative views of Buchanan, such as claiming that he was a neoclassical or otherwise mainstream economist. Finally, I conclude with some closing remarks.

With such differing points of view as to which label to attach to Buchanan, there would seem to be some confusion or disagreement as to what it means to belong to either the Austrian or neoclassical school. And so, following the advice of Voltaire (1843) who wrote, "Define your terms... or we shall never understand each other," it is important to describe what is meant by both neoclassical economics and Austrian economics. I will then provide examples of how Buchanan should be placed in the Austrian camp.

\section{Definitions}

E. Roy Weintraub (2002: p1) briefly summarizes neoclassical economics as buyers maximizing their utility and producers maximizing their profits, both subject to relevant constraints. There are subjective elements to price determinations, leading to buyers paying 
more for an object than it is worth by strict classical definitions. Value was not only determined by costs of production but also by the relationship between the object and the owner. Additionally, individuals and firms make their choices at the margins; they will always continue to buy or produce if utility or profits are increasing, ceasing action the moment the increase stops. Weintraub (2002: p2) expands on the maximizing principle by describing three fundamental assumptions within neoclassical economics:

1) People have rational preferences among outcomes;

2) Individuals maximize utility and firms maximize profits;

3) People act independently based on full and relevant information.

With these assumptions in place, neoclassical models depict an economy that is always in equilibrium. The popularity of neoclassical thinking "is connected to the 'scientificization' or 'mathematization' of economics in the twentieth century." (Weintraub, 2002, p3) It has become so prevalent, in fact, Weintraub (2002: p1) quipped that instead of President Richard Nixon's statement "We are all Keynesians", he should have said "We're all neoclassicals now, even the Keynesians."

Defining Austrian Economics isn't as cut and dry. The origins of the Austrian school date back to the late $19^{\text {th }}$ century with Carl Menger, but since then the school and its label went through its own evolution from Menger to Mises, Hayek, and others. According to Kirzner (2008: p8), because of this indirect developmental path, "the term 'Austrian Economics' has come to evoke a number of different connotations in contemporary professional discussion." Ebeling addresses these "divisions" within the Austrian school:

We need to keep in mind that there never was a uniform Austrian School of Economics. While Menger's writings were the beginning of the Austrian School, there emerged differences of emphasis and approach... Rather than be dismayed or concerned about "divisions" within the Austrian School, it is really a sign of vibrant growth and innovation, as different individuals see possibilities and avenues for research and development within those generally shared ideas that make up the starting points of the Austrian approach. (Northwood University, 2010, p8)

Baird (1989) examines the etymology of "Austrian Economics" and presents the following five tenets as forming the backbone of the approach:

1. Subjectivism on both demand and supply sides 
2. Focus on methodological individualism

3. Focus on exchange rather than optimization

4. Focus on market processes rather than equilibrium states

5. Understanding that economics is an "explanatory" rather than "exact" science

(According to Kirzner (2008: p6), Fritz Machlup had frequently listed six main ideals of Austrian economics, while Boettke (2008: pp 2-6) came up with his own list of ten separate tenets. While all the lists certainly have major similarities, the differences would appear to prove Kirzner's observation about differing connotations.)

It is interesting to note that while some economists might equate the term 'Austrian Economics' with an approach based on propositions like those listed by Baird (1989: p203), Boettke (2008: pp 2-6), or Kirzner (2008: p6), there are also those both within and without the economic profession for whom the term "has come to be associated less with a unique methodology, or with specific economic doctrines, than with libertarian ideology in political and social discussion." (Kirzner, 2008, p8) Kirzner describes Murray N. Rothbard as one who has reinforced this view. This only serves to reinforce the necessity of "defining our terms" when debating which school Buchanan may belong to.

\section{Buchanan's Background and Influences}

Buchanan entered the economics PhD program at the University of Chicago in 1945, after serving four years in the United States Navy. While he doesn't describe his young adult years as being particularly political, he grew up in a predominantly "Roosevelt Democrat" household. On attending a predominantly conservative University of Chicago, he stated "[h]ad I known about the ideological character of the Chicago faculty I might have chosen to go elsewhere." (Buchanan, 2007, p4) By his own description, he entered Chicago as a "libertarian socialist... antistate, antigovernment, antiestablishment... [including] the establishment that controlled the United States economy." (Buchanan, 2007, p5)

This somewhat radical sentiment did not last for very long, however, thanks to two events during his time at Chicago. During his first term, Buchanan was a student in Frank Knight's price theory course, and it was there that he says he converted to a free market enthusiast. Throughout the remainder of his time as a student, as well as after completing his $\mathrm{PhD}$, Knight remained a strong intellectual influence on Buchanan. As quoted in Formaini (2003: p1), Buchanan explained that from Knight he was taught "the message that there exists no god whose pronouncements deserve elevation to the sacrosanct, whether 
god within or without the scientific academy. Everything, everyone, anywhere, anytime - all is open to challenge and criticism."

Certainly, the sins of the father, or in this case, the views of the professor, shall not be visited upon the student. But it can clarify Buchanan's approach to economic thought to briefly examine the major influences on his development. Frank Knight is one of the founders of the Chicago School of economics, which is certainly neoclassical. A straight line can be drawn from Knight to neoclassical thinkers such as Friedman and Stigler.

(Henderson, 2007, p1)

Additionally, Knight took issue with some aspects of the Austrian school. Klein (2016: p1) called him a "harsh critic of Austrian capital theory" and pointed out that he was "a key developer of perfect competition theory - anathema to Austrians..." In an interview posted online on a Northwood University blog, Dr. Richard Ebeling (Northwood University, 2010: p4) expands on this view, pointing out that Knight "did not agree with Mises or Hayek about the impossibility of economic calculation under socialism, and that he was very far from being an advocate of laissez-faire."

Based on this cursory examination, one could label Knight as a neoclassical, like his proteges Friedman, Stigler, and maybe even Buchanan. And perhaps, as will be seen later, this is exactly what some economists have done. But as Ebeling (Northwood University, 2010: p4) goes on to explain, Knight also showed some affinity towards Austrian ideals. Like the Austrians, Knight "believed that economics could not be moulded along the lines of the natural sciences" and that there were "limits to the application of mathematics in economics." (Indeed, Boettke (1998: p24) explains that through Knight, Buchanan came to the same conclusion that economics is not a science in the traditional sense.) Knight stressed the "importance of introspection as a source of knowledge in the study of human action and choice," and "argued that one could not ignore the "subjectivist" elements to social and economic processes." (Northwood University, 2010, p4) Clearly, Frank Knight did not fit squarely into a single classification of economic school of thought. At a minimum, he was someone who proves the need for some fluidity in assigning such labels.

The other major influential event for Buchanan's development as an economist was his chance reading of an 1896 paper on taxation by Knut Wicksell, wherein Wicksell discussed changing the rules by which political agents act and questioned the benevolence of said agents. While Wicksell is associated with the Stockholm School of economics, his work is generally credited as leading to developments in public choice theory, Keynesian economics and the Austrian school. (Formaini, 2004, p3) It was from Wicksell, according to Boettke (1998: p24), that Buchanan learned that "politics needs to be understood in an 
exchange framework." This is certainly an "Austrian-esque" approach to politics. Additionally, Formaini (2003: p1) points out that Buchanan learned from Wicksell that "governments are not efficient, purely altruistic entities that effortlessly correct market imperfections...[they] are aggregates of individuals pursuing private rather than public interest..." This focus on individualism within governments also fits with the Austrian school's approach. So, again, we have an economist who was a major influence on Buchanan whose work can be placed both within and without the Austrian school umbrella.

\section{Buchanan and... Cost and Subjectivism}

Both neoclassicals and Austrians would agree that utility is subjective. But from the days of Alfred Marshall and the neoclassicals who followed in his footsteps, cost determination was objective, based on the intrinsic value of the resources utilized in production. As DiLorenzo (1990: p181) explains, "[t]o neoclassical economists cost is objective in that it can be estimated ex post by external observers, even though market values are set by the subjective evaluations of market participants." By implication, then, there is no choice involved in an objective cost theory. However, at least according to the Austrian viewpoint, all economic actions involve choices made by individual human minds. This means subjective preferences. So, for Austrians, "[costs] are... subjective because they are themselves determined by the value of alternative uses of scarce resources." (Boettke, 2008, p3) Buchanan took the same view.

James Buchanan published his first book, Public Principles of Public Debt, in 1958. It was his attempt to "demonstrate the fallacies of the Keynesian orthodoxy" via the political theories he had been developing while also stressing the importance of conducting economic analysis under the constraint that real individuals make real choices. (Boettke, 1987, p9) One of the problems Buchanan saw with the new approach to fiscal policy was the focus on aggregation and the lack of understanding that governments and nations were not organic bodies but rather are made up of individuals. Buchanan wrote in that first book, as quoted in Boettke (1987: p9), "It is misleading to speak of group sacrifice or burden or payment or benefit unless such aggregates can be broken down into component parts which may be conceptually or actually imputed to the individual or family units in the group." Because of the reliance on aggregation as well as the nature of public debt, the Keynesian model lost sight of when the costs are incurred and by whom. As Buchanan saw it, "the problem with fiscal theory, therefore, was a misunderstanding of the basic principles of opportunity cost and economic decision-making." (Boettke, 1987, p9) 
In 1969, to further clarify his view on the problems with public debt, Buchanan published Cost and Choice: An Inquiry in Economic Theory. Boettke (1987: p9) referred to Cost and Choice as "Buchanan's most Austrian book." And according to DiLorenzo (1990: p180), Buchanan considers the book "to be his most important theoretical contribution." Buchanan explains his problem with the objective cost theory used in the Keynesian public debt analysis by asking:

For whom is this cost relevant? This becomes a critically important question. Cost as just defined is faced in the strict sense only by the automaton, the pure economic man, who inhabits the scientist's model... In the strict sense, this theory is not a theory of choice at all. Individuals do not choose; they behave predictably in response to objectively measurable changes in their environment. (Buchanan, 1969, p40)

While Buchanan (1969: pXV) states in the preface to the book that "[l]atter-day Austrians especially may suggest, with some justification, that the theory developed is properly labeled 'Austrian,"' he gives much of the original credit to Philip Wicksteed. As Buchanan (1969: p40) explains it, economists from the London School of Economics as well as Mises and Hayek refined what Wicksteed had published in his 1910 work The Common Sense of Political Economy. In describing this combined work on subjective cost theory, Buchanan (1969: p41) asserts that:

The essential element in this concept is the direct relationship between cost and the act of choice, a relationship that does not exist in the neoclassical predictive theory. In the London-Austrian conception, by contrast, cost becomes the negative side of any decision, the obstacle that must be got over before one alternative is selected. Cost is that which the decision-taker sacrifices or gives up when he makes a choice. It consists in his own evaluation of the enjoyment or utility that he anticipates having to forego as a result of selection among alternative courses of action.

Buchanan (1969: pp 42-43) does, however, acknowledge the existence of some objectively observable costs. Some costs are "choice-influencing," and these are subjective in nature and are directly influential in affecting the choice. "Choice-influenced" costs, on the other hand, are those costs that are incurred because of the choice having been made and are objective in nature. As Buchanan explains it: 
Having committed himself to one course of action rather than another and having presumably made some rational estimation of the costs that this would embody, the individual "suffers" the consequences. He may not regret his prior decision, but, at the same time, he may undergo "pain" or "sacrifice" when he is required to reduce his utility levels. Whether or not choices were rightly or wrongly made has little direct relevance to the existence of this choice-influenced "cost." (Buchanan, 1969, p 42)

Buchanan (1969: p43) makes an important observation regarding the difference between the two types of cost: "Strictly speaking, only choice-influencing cost represents an evaluation of sacrificed "opportunities." It might therefore be reasonable to limit the term opportunity cost to this conception." And it is these costs that are relevant when examining an economy that is not operating at full equilibrium:

the whole purpose of the economic theory in which cost is relevant is to demonstrate how choices made in nonequilibrium settings will generate shifts toward equilibrium. And choices in disequilibrium must be informed by opportunity costs that cannot, even indirectly, be represented by measured outlays. In disequilibrium, the opportunity costs involved in taking the "wrong" decision must include the profits foregone in the rejection of the alternative course of action. (Buchanan, 1969, pp 46-47)

As Baird (1989: p222) explains, the above viewpoint is like that of the Austrians.

One important implication of Buchanan's subjective cost theory is on the true costs of taxes. The neoclassical approach to the cost of taxation focuses on who pays the taxes to the government and what are the welfare costs of those taxes. Neoclassicals consider both items to be objectively measurable. As Buchanan (1969: p50) explains, neoclassical public finance theory "examines the choice behavior of individuals and firms, but this is not the choice behavior that involves either the financing of public goods or the selection among taxing alternatives. The individual or firm is assumed to be subjected to an imposed change in the alternatives of private or market choice."

For DiLorenzo (1990: pp 183-184), an economist in the neoclassical approach to tax policy becomes an "advisor to political decision makers." He suggests the tax policy that would raise the necessary revenue while also making sure to minimize the welfare costs to society. In this scenario, the economist "constructs a social welfare function even if the... 
taxpayers have no input into the construction of the social welfare function or to the choice of tax instruments."

For Buchanan, the neoclassical approach to taxes is, in DiLorenzo's words, "inherently authoritarian." In the true opportunity-cost sense, costs are dependent on choice, and choices are made by individuals. Without being able to identify and analyze those individuals, as would occur in a pure aggregation model, one cannot determine the actual costs.

\section{Buchanan and... Methodological Individualism}

The choices made in the market, whether that market is economic or political, are made by individuals, not collectives. In economics, firms are often discussed as wanting to maximize profits and governments are said to raise taxes. But these groups are made up of individuals making those choices. "Only individuals think, evaluate, plan, and act. Clubs, firms, states, nations, and publics are merely groups, or collectives, of individuals." (Baird, 1989, p205) To understand what a group is doing one must examine what the individuals in that group are doing. This sentiment is shared by neoclassicals and Austrians alike, and it is a major part of public choice theory.

Throughout his career, Buchanan was a very prolific writer. But certainly, his most well-known work came in 1962 when he co-authored The Calculus of Consent-Logical Foundations of Constitutional Democracy with Gordon Tullock. It was this effort that laid the groundwork for public choice theory that would dominate Buchanan's career and result in him being awarded the Nobel prize in 1986. In describing public choice theory, Tullock says "[b]y assuming that voters, politicians and bureaucrats are mainly self-interested, public choice uses economic tools to deal with the traditional problems of political science." (Tullock, 2008, p1)

Some non-economists reading that description might focus on the second part regarding the use of economics to examine politics. But they would be missing out on a vital assumption - that politicians are focused on their own self interests. The government is not acting as one collective body, making choices and taking actions on its own. Instead, it is made up of separate individuals, each with his or her own desires and preferences. And so, to fully understand the decisions made by governments, one must examine the interests of those individuals with the most power. Once that is understood as given, expecting a politician to act any differently from an entrepreneur looking to maximize profits is pure folly. Interestingly, this viewpoint had not been part of the orthodox views of the time. As Tullock 
(2008: p2) explained, the mainstream view was quite the opposite: "Writers who did hold [these views], like Machiavelli in parts of The Prince, were regarded as morally suspect and tended to be held up as bad examples rather than as profound analysts."

In 1978, Buchanan was invited by the Institute of Economic Affairs to give a lecture at a seminar on "The Economics of Politics." In it, he began by explaining why the sub-field of public choice has been called the "economic theory of politics." He says that this theory of politics is economic in nature because "like traditional economic theory, the building blocks are individuals, not corporate entities, not societies, not communities, not states. The building blocks are living, choosing, economizing persons." (Buchanan, 1978, p5) He is clearly differentiating the focus on the individual within public choice from the more aggregate-centric approaches in orthodox economics and political theory.

In a paper describing how he and Gordon Tullock had come up with the ideas in The Calculus of Consent, Buchanan (2012: p254) states that both he and Tullock approached the topics based on "methodologically individualistic foundations." In providing a definition of public choice, Buchanan (1984: p13) stated "public choice theory is methodologically individualistic, in the same sense that economic theory is. The basic units are choosing, acting, behaving persons rather than organic units such as parties, provinces, or nations. Indeed, yet another label for the subject matter here is "An Individualistic Theory of Politics."

In fact, the importance in economics of studying the individual was a long-held belief by Buchanan. As Boettke (1998: p25) explains, Buchanan had challenged Keynesianism in his 1958 book Public Principles of Public Debt. In it, Buchanan took issue with how much aggregation was present in Keynesian fiscal theory. According to Boettke, because of this reliance on the aggregate rather than the individual, Buchanan felt that "fiscal theorists were unable to address the problem of who pays for the creation of public goods... the principle of opportunity cost and economic decision-making was forgotten." (Boettke, 1998, p25) As stated above, both Boettke (2008) and Baird (1989) describe this same individualism as one of the main tenets of Austrian economics.

Of course, it is hardly controversial to point out that neoclassical economics also holds methodological individualism in high regard. But economists such as Thomas DiLorenzo claim that the rigor with which both Buchanan and the Public Choice school, like the Austrian school, apply the ideals of methodological individualism is unlike other schools. To him, the fact that both public choice and Austrian economists focus on the analysis of the individual "has spared [them] from many of the mistakes of what might be called collectivist economics." (DiLorenzo, 1990, p189) He gives Buchanan credit for "greatly improving our 
understanding of the political process by scrapping the 'organic' view of collective action." Buchanan wrote in 1968:

Most... economists take an approach different from my own, and one that I regard as both confused and wrong. In my vision of social order, individual persons are the basic component units, and "government" is simply that complex of institutions through which individuals make collective decisions, and through which they carry out collective as opposed to private activities. Politics is the activity of persons in the context of such institutions. (Buchanan, quoted in DiLorenzo, 1990, p189)

At a minimum, this economic theory of politics by Buchanan and his focus on methodological individualism might be straddling both neoclassical and Austrian economics. But one could make the argument that Buchanan takes it further than the neoclassicals did.

\section{Buchanan and... Exchange over Optimization}

Lord Lionel Robbins once defined economics as "the science which studies human behavior as a relationship between ends and scarce means which have alternative uses." (Robbins, 1932) Since that publication, neoclassical economists have been laser focused on finding the optimal value or utility among those alternative uses. "Constrained maximization - the mathematics of the Lagrangian multiplier - has pride of place in most intermediate and graduate level price theory textbooks." (Baird, 1989, p205) But as Baird goes on to say, Austrian economists, at least modern practitioners, rebel against this definition and focus instead on the process of individuals acquiring the necessary information regarding the scarcity mentioned by Robbins. "Exchange with others in pursuit of broadly conceived personal gain is the quintessential economic action... on which economic analysis should focus its attention." (Baird, 1989, pp 205-206) Additionally, focus should be paid to who exactly is taking part in these exchanges. Following the previous notions of subjectivism and individualism, understanding the identity of the actors involved in the market exchanges is vital. This focus, known as catallactics, centers on "relationships that emerge in the market, the bargaining that characterizes the exchange process, and the institutions within which exchange takes place." (Boettke, 2008, p2)

Buchanan took great issue with Robbins and his definition for economics in his 1964 paper, "What Should Economists Do?" He begins by confronting Robbins head on: "I propose to take on Lord Robbins as an adversary and to state, categorically, that his all-too- 
persuasive delineation of our subject field has served to retard, rather than to advance scientific progress." (Buchanan, 1964, p214) His main issue with Robbins (and the economists who subscribe to the same view) centers on the lack of attention on the individual making the choices about the resources. "Search [Robbins] as you will, and you will not find an explicit statement as to whose ends are alternatives... [He is] wholly silent on the identity of the choosing agent." (Buchanan, 1964, p214)

It should be noted here that there was some pushback at the time against Buchanan and his associating Robbins with the notion that economics is merely an exercise in allocative mathematics. Indeed, some of that criticism was from economists who generally agreed with Buchanan's desire to focus on individualism, exchange, and the market. In one review of Buchanan's paper, Israel Kirzner explains:

Buchanan's quarrel is not, or ought not to be, with Robbins' own emphasis on allocation and choice at all, but is properly to be restricted to that literature that is concerned, in the name of economics, with the attainment of efficient solutions, and that evaluates the market primarily with respect to its efficiency as an "allocative mechanism." (Kirzner, 1965, p258)

This blind devotion to maximization in mainstream economics while ignoring the involved actors is, according to Buchanan, "not legitimate activity for practitioners in economics." He goes so far as to suggest that if this is the preferred approach, then further study in the field should be left to applied mathematicians rather than "economists." He even complains about the word "economics," preferring "catallactics" or "symbiotics." For Buchanan, the exchange is the thing. "I want economists to modify their thought processes, to look at the same phenomena through 'another window,' to use Nietzsche's appropriate metaphor. I want them to concentrate on 'exchange..." (Buchanan, 1964, p217)

It is interesting that Buchanan had such a focus on catallactics despite his background at the University of Chicago with Frank Knight. In his autobiographical work, Economics from the Outside In, Buchanan laments about how Knight, though somewhat vague in his own beliefs as to what economics was about, never abandoned the "allocatingmaximizing paradigm which tends to distract attention from the coordination paradigm that [Buchanan has] long deemed central to the discipline." (Buchanan, 2007, p71) Buchanan seems to also find this interesting. In fact, he appears to align himself with his Austrian peers regarding his own focus on catallactics. "Had I received 'better' pre-Chicago training in economics...[]]ike so many of my peers, aside from the few who were exposed early to 
Austrian theory, I might have remained basically an allocationist." (Buchanan, 2007, p71) (emphasis added)

In an interview published by the Federal Reserve Bank of Richmond, Buchanan was asked to describe the difference between the allocationist-maximization paradigm, which the interviewer describes as neoclassical, and most of Buchanan's research which has been within the catallactic-coordination paradigm. Buchanan's response serves to reinforce the argument that his work differs from the neoclassicals:

Economics, as it was transformed by Paul Samuelson into a mathematical discipline, required practitioners to have something to maximize subject to certain constraints. This contrasts with the catallactic coordination paradigm, which starts out with individuals simply trading with each other. You examine this process and build up into a system of how markets emerge and become integrated. It's a very different conceptualization of the whole economic process. (Steelman, 2004, p5)

In other writings, Buchanan expressed another criticism of the focus on utility maximization. In a lecture given in 1978, "Natural and Artifactual Man," he explains that with each choice made, the economic actor himself changes. He compares this to the notion put forth by Heraclitus that a man never steps into the same river twice. After each step and economic choice, the river and the market continue to flow, and as time passes the man and the entrepreneur changes. Solving the utility maximization problem does not solve "anything that remains stable for more than the logical moment for analysis." (Buchanan, 1979, p109) With this argument, Buchanan is not only expressing distaste in a focus on constrained maximization, but he is also stating an affinity towards the market process and how economic actors and situations evolve through the various exchanges that take place.

Buchanan further discussed the importance of understanding that economic actors are constantly evolving along with their preferences:

Man wants liberty to become the man he wants to become. He does so precisely because he does not know what man he will want to be in time... Man does not want liberty in order to maximize his utility, or that of the society of which he is a part. He wants liberty to become the man he wants to become. (Buchanan, 1979, p112)

Buchanan is asserting not only that man is not looking to maximize his utility, but that he is looking to change his very self and that man is unaware of what that future version will be 
like. The idea of pre-determined preferences, therefore, is anathema to the kind of economics that Buchanan is discussing here. Rizzo (2014), in discussing this theme, stated that "Buchanan's idea of the individual changing or becoming through time is an idea congenial to Austrian economics." (Rizzo, 2014, p144)

\section{Buchanan and... Market Process rather than Equilibrium}

The result of the constrained maximization problems previously mentioned is the determination of the endpoint for the economy - equilibrium. This destination is the primary focus of neoclassical economics. Austrians, however, are more interested in the journey than the destination. Such equilibrium can only be achieved through full information, which neoclassicals take as given. But no single party possesses all the necessary information necessary to reach such a state. As one goes through the market process, capitalizing on the various relationships present, additional information is acquired. As the body of information grows, including potential profit opportunities, the entrepreneur can use that information to gain advantage and wealth. However, other entrepreneur's will also eventually gain said knowledge and old profit opportunities dissipate. With each action of each entrepreneur, and the movement of the relevant information, the market is forever in flux, never truly achieving the equilibrium state that neoclassicals insists is always present. (Baird, 1989, pp 206-207)

Once again, Buchanan's writings show a distinct affinity for the market process viewpoint of the Austrians. In arguing what he felt economists "should" do, Buchanan called for a move away from the "theory of resource allocation" and instead move toward a "theory of markets." (Buchanan, 1964, p214) As alluded to in the previous section, he believed the market was what can be described as a living organism, continually changing and evolving with each exchange. Relationships are created, information is gained, and new profit opportunities arise. With this constant movement, there is no final resting point. There are always new relationships to form as old ones die, there is always additional information gained as old information becomes irrelevant, and as profit opportunities dry up new ones are created. To Buchanan, this reliance on exchange and the market process is not a new way of studying economics, and he shows this by quoting what he refers to as a "muchneglected principle" from Chapter II of The Wealth of Nations where Smith describes the very market process that Buchanan espouses:

It is the necessary, though very slow and gradual, consequence of a certain propensity in human nature which has in view no such extensive utility; the propensity to truck, barter, and exchange 
one thing for another. (Smith as quoted in Buchanan, 1964, p213) (emphasis added)

This aspect of human nature that Smith is talking about is what Buchanan says economists should be focusing on. He goes on to say in that same 1964 paper that economists should focus not just on the specific activities, but also the variety of relationships that form because of man's "propensity to truck and to barter."

One of the major assumptions of the neoclassical approach is that markets are perfectly competitive. This is a result of the "full and relevant information" referred to previously. Buchanan attacks this assumption on market competitiveness directly, and here again he talks about the market process and about exchange:

A market is not competitive by assumption or by construction. A market becomes competitive, and competitive rules come to be established as institutions emerge to place limits on individual behavior patterns. It is this becoming process, brought about by the continuous pressure of human behavior in exchange, that is the central part of our discipline, if we have one, not the dry-rot of postulated perfection. (Buchanan, 1964, p218)

Additionally, he seems to argue against the notion of setting up mathematical equations to determine the general equilibrium point, something that Austrians would also argue against.

A solution to a general-equilibrium set of equations is not predetermined by exogenously-determined rules. A general solution, if there is one, emerges as a result of a whole network of evolving exchanges, bargains, trades, side payments, agreements, contracts which, finally at some point, ceases to renew itself. At each stage in this evolution towards solution, there are gains to be made, there are exchanges possible, and this being true, the direction of movement is modified. (Buchanan, 1964, p218)

Buchanan also took the view, which Baird (1990) likens to Hayek, that markets are not explicitly designed by humans but rather they emerge from human action:

The "market" or market organization is not a means toward the accomplishment of anything. It is, instead, the institutional embodiment of the voluntary exchange processes that are entered into by individuals in their several capacities. This is all that there is to it. Individuals are observed to cooperate with one another, to 
reach agreements, to trade. The network of relationships that emerges or evolves out of this trading process, the institutional framework, is called "the market." (Buchanan, 1964, p219)

While Buchanan may not have explicitly stated an effort to promote Austrian ideals with his views on competition and markets, said ideas were understandably supported by those in the Austrian camp. Kirzner, himself an Austrian, stated the he concurs "wholeheartedly" with most of Buchanan's views, while taking pains to point out that Austrian heavyweights such as Mises and Hayek have already expressed similar views (and in a stronger fashion). (Kirzner, 1965, p257) DiLorenzo, another prominent Austrian, sees these views by Buchanan as clearly Austrian in nature:

This approach helps us understand why, in perfect competition, there is no competition (or any trade, for that matter). It also reveals how a market is not competitive by definition, as in the neoclassical model, but that a market becomes competitive... Thus, Buchanan's view of the market system may properly be labeled Austrian. (DiLorenzo, 1990, p191) (emphasis added)

\section{Buchanan and... Economics is not an "exact" science}

This focus on market exchanges rather than calculations of the equilibrium end points naturally leads to the belief among Austrians that "economics is not an exact science and that the methodology of exact sciences is not appropriate in economics." (Baird, 1989, p207) For Austrians, there are far too many subjective variables for mathematics to adequately explain any economic conditions. This is in full contradiction to the neoclassical approach. "The neoclassical mainstream is wont to express assumptions and develop models by the manipulation of mathematical equations. Austrians claim that such exercises are redundant at best and often completely misrepresent the actual character and essence of human action." (Baird, 1989, p208) Austrians may occasionally desire to use mathematical models simply as a clarification device or to illustrate a specific point, but such models are not what economists should be relying on.

Economist Gregory Christainsen once described Buchanan by saying "[he] makes little use of mathematics, and in none of his publications, not even one, has he undertaken statistical estimates." (Christainsen, 1988, p11) Indeed, throughout the discussion thus far, it can be concluded that Buchanan took issue with some of the more mathematically based applications of economics. He clearly felt there were too many subjective or otherwise 
unknown (and unpredictable) variables involved to make precise mathematical equations worthwhile. This was a sentiment that Buchanan felt from early in his career, when he and Warren Nutter established the Thomas Jefferson Center for Studies in Political Economy at the University of Virginia in the mid to late 1950's.

Boettke (2014: p54) explained that both Buchanan and Nutter were concerned at the time that modern economics was losing sight of the contributions of such thinkers as Adam Smith and John Stuart Mill in favor of "excessive formalism under the influence of Samuelson and excessive aggregation as a consequence of Keynes." Due to those two developments, the focus of economics was not on the market framework and exchange relationships within that market but rather it was on "equilibrium outcome, and the level of aggregate economic performance." It was these concerns that led to Buchanan and Nutter to creating the Center. According to Buchanan, the establishment of that Center "encouraged [him], and others, to counter the increasing technical specialization of economics and allowed me to keep the subject matter interesting when the discipline, in more orthodox hands, threatened to become boring in the extreme." (Buchanan, 2007, p16)

Buchanan had previously used the "interesting vs. boring" argument against the increasing dependency on mathematical models in economic departments. Despite appearances, it wasn't simply viewing mathematical models with an elitist's disdain. Rather, he saw them as superfluous. "As Frank Knight used to say, most of the empirical work in economics is 'proving water runs downhill,' a proposition that the Austrians would scarcely question." (Buchanan, 1979, p88) (emphasis added) In the same paper, Buchanan goes on to describe what he saw as "wasted time" studying empirical models, and again decrying the "dullness" of it all:

The young and aspiring economist who becomes the expert empiricist has necessarily sacrificed training time in learning more about the process to which his highly polished technical tools are to be applied. These gaps in the training of modern economists are beginning to show up in many forms, not the least of which is the deadly dullness that dominates whole departments in many universities and colleges. (Buchanan, 1979, p88)

This sentiment that focusing so much on "new" mathematical economics to the exclusion of the more philosophical ideals put forth by classic thinkers was a "waste of time" and "unnecessary" seemed to be a strong one for Buchanan as it was repeated in one form or another throughout his writings. One additional example is from his essay "Politics without Romance...": 
Ecclesiastes tells us that there is nothing new under the sun, and in a genuine sense, such a claim is surely correct, and especially in the so called social sciences. (I am reminded of this every week when I see my mathematically inclined younger colleagues in economics rediscovering almost every wheel that older economists have ever talked about.) (Buchanan, 1984, p11)

In addition to Nutter and the other economists at the University of Virginia, Buchanan asserts he shares this viewpoint with Hayek and Knight, saying "Hayek and Knight were sharply critical of any attempts to convert economics into a discipline analogous with a natural science." (Buchanan, 1979, p84) So Buchanan can appropriately be placed in the camp of Austrian economics, at least the Hayekian branch, on the issue of economics as an exact science.

However, Buchanan and the Austrians did acknowledge that there could be the occasional need for such an approach. In discussing the reliance on mathematics in the allocation-maximization approach, Buchanan says:

I want to note especially here that I am not, through rejecting the allocation approach, decrying the desirability, indeed the necessity, for mathematical competence. In fact, advances in our understanding of symbiotic relationships may well require considerably more sophisticated mathematical tools than those required in what I have called social engineering. (Buchanan, 1964, p221)

Buchanan did imply though that empiricists should "stay in their lane," as it were. "I find no difficulty at all in allowing the general equilibrium theorist to do his work alongside his subjectivist, nonmathematical counterpart, provided that he does not slip into error by somehow imputing, even at some conceptual level, objective meaning into his wholly imaginary constructs." (Buchanan, 1979, p89) 


\section{In his own words}

It is worth looking at comments that Buchanan made himself that might give some insight as to where he would fit. Here I examine comments that otherwise do not fit in any of the above sections.

After winning the Nobel Prize, Buchanan was interviewed for the Austrian Economics Newsletter in 1987 and the subject of which school he might belong to came up briefly. The interviewer asked, "Do you consider yourself an Austrian economist?" Buchanan replied, "I certainly have a great deal of affinity with Austrian economics and I have no objections to being called an Austrian. Hayek and Mises might consider me an Austrian but surely some of the others would not." (Thornton, et al., 1987, p4) This is not exactly a clear declaration on being an Austrian, but it does suggest a leaning in that direction. However, even Buchanan acknowledges that there is some disagreement. Whether that disagreement is due to the varying criteria in classifying Austrian economics, confusion over the meaning of Buchanan's theories, or perhaps guilt-by-association with Tullock or even Stigler or Coase is unclear.

In the same interview, the topic of "subjectivism" was brought up:

$\mathrm{Q}$ : There is a wide spectrum of subjectivism from mainstream orthodoxy to Shackle and Lachmann. Where do you place yourself on that spectrum?

A: Well, I'm certainly much closer to Shackle than I am to the mainstream. I've been tempted to go completely along with Shackle and become a very radical subjectivist. But I recognize that if you go all the way down that road you end up with a nihilistic position. I'm somewhere between von Mises and Yeager on the one hand and Shackle on the other. The person who comes closest to my methodological position is Jack Wiseman. (Thornton, et al., 1987, pp 3-4)

As written in his obituary, "Jack Wiseman's distinctive and original academic contributions were in the fields of public finance / public sector studies, industry, public choice and Austrian economics." (Hartley, 2000, pF445) So Buchanan's statement does seem to indicate a personal affinity towards the Austrian school.

One more example from this 1987 interview also seems to indicate at least a similarity between Buchanan and the Austrians. Buchanan explains "I didn't become 
acquainted with Mises until I wrote an article on individual choice and voting in the market in 1954. After I had finished the first draft I went back to see what Mises had said in Human Action. I found out, amazingly, that he had come closer to saying what I was trying to say than anybody else." (Thornton, et al., 1987, p10)

In an essay entitled "General Implications of Subjectivism in Economics," Buchanan begins by saying:

I have often argued that the "Austrians" seem, somehow, to be more successful in conveying the central principle of economics to students than alternative schools, enclaves or approaches... [M]y hypothesis depended, of course, on a definition of just what the most important central principle in economics is. The principle that exposure to economics should convey is that of the spontaneous coordination which the market achieves. The central principle of economics is not the economizing process; it is not the maximization of objective functions subject to constraints. (Buchanan, 1979, p81)

He closes the essay by saying:

Unfortunately, most modern economists have no idea of what they are doing or even of what they are ideally supposed to be doing... I think I know what I am doing, and I think that most of those who espouse a variant of Austrian subjectivist economics know what they are doing... I suppose that all of this finally reduces to an admonition to keep the faith, whether we want to call this doing economics, subjectivist economics, Austrian economics, or something else. (Buchanan, 1979, pp 90-91)

While he doesn't say it explicitly, Buchanan does appear to be making the case that he is an Austrian. The first quote says that both he and the Austrians follow the same "most important central principle" of economics. The second quote begins by differentiating himself from the Austrians, "I know... and the Austrians know..." But then he closes it with "whether we want to call this...Austrian economics..." Perhaps the "we" is meant to refer to non-Austrian subjectivist economists, or perhaps it is meant to refer to the Austrians and himself. Either way, it would be difficult to argue that he sees himself as anything other than Austrian.

The final quote comes from an interesting find by Peter Boettke. While conducting research within the Buchanan archives, Boettke came across a letter that Buchanan wrote in 
1962 to the members of the Mont Pelerin Society. (Buchanan eventually became president of the society, a position previously held by Stigler and Friedman, as well as Hayek. One could see how this joint association with neoclassicals and Austrians might add to the debate over the proper classification of Buchanan's economics.) Boettke (2014: pp 63-64) quotes from Buchanan's letter thusly:

The appropriate role of the society is that of insuring the survival of a set of ideas and ideals, once widely honored, but now held only by a minority... [S]terility is the certain result if a deliberate clinging to old fashioned clichés and concepts is fostered. Legitimate survival of the time-honored ideals of the free society can be achieved only through a continuously critical examination of the bases of libertarian doctrine, along with tolerance of change in the structure of libertarian thought.

I find this quote to be both interesting and relevant, even though it doesn't explicitly express a view on one form of economic thinking or another. It does, however, speak to the introspective and philosophical aspects of what Buchanan felt economists should do. It was written less than two years prior to Buchanan giving his presidential address to the Southern Economics Association, which was later turned into his 1964 paper quoted repeatedly here entitled "What Should Economists Do?" In the letter, he speaks of both respecting and critically examining "ideas and ideals." As Boettke (2014: p64) concludes, this is what Buchanan sought with the research programs he helped create. 'The 'saving the books' and 'saving the ideas' project... was an upward and onward march out of the hyperspecialization of mid-twentieth century social science, and an effort instead to integrate the disciplines of philosophy, politics and economics into a modern political economy and social philosophy program." The "mid-twentieth century social science" refers almost certainly to the neoclassical approach, and the more introspective program that Boettke is speaking of can certainly be taken as more Austrian-leaning economic research.

\section{Other viewpoints}

As stated at the beginning, there are some who have labeled James Buchanan as a neoclassical economist, or at least a bridge between neoclassicals and Austrians. While these claims do exist, they number far less than the number of papers detailing Buchanan's Austrian leanings. (However, this could be a form of "survivor bias." Is it possible that Austrian economists are far more likely to write a "History of Economic Thought" analysis of Buchanan than a neoclassical economist? And, wouldn't the likelihood of a pro-Austrian 
view of Buchanan be higher from an Austrian than from a neoclassical?) A few of the claims tend to be of the "guilt by association" nature. But for many of these claims, it depends not only on how narrow their definition of Austrian economics is, but also how much of the public choice canon they attribute to Buchanan rather than Gordon Tullock or other public choice theorists.

In the paper entitled "The Ongoing Methodenstreit of The Austrian School," Jesus Huerta de Soto lays out the differences between Austrians and neoclassicals. He provides his own definitions as to what characterizes an Austrian economist, most of which coincide with previously referenced lists such as by Boettke or Machlup. He does make some slight refinements, however. For example, he states:

For the Austrian theorists, economic science is conceived as a theory of action, rather than a theory of decision and this is one of the features that most clearly distinguishes them from their neoclassical colleagues... Therefore, for the Austrians, economics, far from being a theory on choice or decision, is a theory on the processes of social interaction... for the Austrians, economics is subsumed under or integrated into a much more general and broad science, a general theory of human action (not of human decision). (de Soto, 1998, p 76-77)

The emphasis on Austrian economics not being a theory of decision or choice may not be a large difference but it might be enough to not allow Buchanan entry into the Austrian school. de Soto then provides a three-column chart. The first column lists various parameters by which he compares Austrians and neoclassicals, the second column contains the Austrian results to those parameters, while the final column contains the neoclassical results. For example, next to "Methodological Starting Point," he lists "Subjectivism" under Austrians and "Methodological Individualism" under neoclassicals. The two final parameters for comparison are "Most recent contributions" and "Relative position of different authors." de Soto lists "Public Choice Theory" and "Buchanan" under the neoclassical column for each, respectively. Unfortunately, he does not comment any further on public choice in general or on Buchanan specifically.

de Soto (2010: pp 209-210) appeared to further explain his position on public choice about ten years later in his book Socialism, Economic Calculation and Entrepreneurship. In providing an analysis of Oskar Lange's "competitive solution" model, he presents a criticism of Lange by Buchanan. He then provides a short background on public choice, saying: "The foundations of the public choice school were undoubtedly laid by Mises himself, when he 
conceived of economics as a very broad science concerned with theoretically studying all processes related to human action." However, this might not be enough to give public choice and/or Buchanan any Austrian credentials in de Soto's view. In the same book, he had previously noted "I agree with DiLorenzo [1988] that the analysis of [the public choice] school has until now been seriously weakened by its excessive dependence on the methodology of neoclassical economics." (de Soto, 2010, p93) So, one can surmise that while de Soto sees the foundation that public choice was built on as being Austrian, it was corrupted or "weakened" by the reliance on neoclassical theories, perhaps by Buchanan himself.

The reference to DiLorenzo by de Soto is from a paper entitled "Competition and Political Entrepreneurship: Austrian Insights into Public-Choice Theory." He begins the paper explaining the connection between public choice and neoclassical theory:

Public choice can be defined as the application of economic theory and methodology to the study of politics and political institutions, broadly defined. Neoclassical price theory has been one of the principal tools of the public-choice theorist, having been applied to address such questions as why people vote, why bureaucrats bungle, the effects of deficit finance on government spending, and myriad other questions regarding the operations and activities of governments... But neoclassical price theory has its limitations, many of which have been investigated by Austrian economists. These limitations have implications for the study of public choice. Namely, if neoclassical price theory is itself flawed, then perhaps its applications to the study of political decision making has produced uncertain results. (DiLorenzo, 1988, p59)

Later in the paper, however, he seems to describe Buchanan as a better alternative to neoclassical theory. He begins by explaining (p63) how neoclassicals prefer perfectly competitive markets because "they promote allocative efficiency." But because Austrians believe all costs are subjective, they have no use for such a model.

To state that a certain allocation of resources is allocatively efficient and maximizes "social welfare" is to assume that benefits and costs are objective and measurable by some outside observer/social engineer. Moreover, to claim that one allocation of resources is superior to another on neoclassical efficiency grounds requires one 
to make interpersonal utility comparisons, a sheer impossibility.

(DiLorenzo, 1988, p63)

This is right in line with Buchanan's Cost and Choice, as discussed above. Indeed, he then cites Buchanan as providing an example of a different approach to efficiency that is individual-centric: "From this perspective, a "better" allocation of resources can only be determined by people themselves, not by professional maximizers of social welfare functions. The standard of evaluation is ultimately consent among individuals." (DiLorenzo, 1988, p64) Perhaps this was an example of viewing public choice as leaning neoclassical but not Buchanan. It is interesting to note that at the conclusion of this paper, DiLorenzo says:

Austrian economics and public choice are two of the most exciting areas of economic research... This article is, if anything, a plea to consider the two research programs as complementary. Economic reasoning can and will be applied to advance our understanding of the political process, but one need not adopt the entire neoclassical economic framework to do so. (DiLorenzo, 1988, p69)

So, in one work, de Soto (1998) is declaring Buchanan and public choice as neoclassical, while also indicating they are "not Austrian." In a later piece, however, de Soto (2010) softens his stance just a bit, allowing for some Austrian influence on public choice by way of Mises, and clarifying his view that public choice has "become" neoclassical. This latter view is then substantiated by referencing DiLorenzo (1988). But that DiLorenzo paper doesn't fully agree with de Soto's conclusions, and is more "friendly" to the idea that Buchanan and perhaps even public choice might fit under the Austrian umbrella.

The notion that Buchanan might lean more toward the Austrians while public choice might be more neoclassical is not entirely foreign or off-base. It can at least in part be traced to Buchanan himself. In his paper "Genesis," he refers to a difference between himself and his Calculus of Consent co-writer, Gordon Tullock: "Economics, defined as a broad and inclusive research program, falls variously along a methodological spectrum between predictive science and philosophical inquiry. If classification is restricted to the polar extremes, Tullock becomes the scientist of the authorship pairing while Buchanan assumes the philosopher's role." (Buchanan, 2012, p254) One could argue from this quote that Buchanan sees himself as the more introspective Austrian economist, believing in the importance of subjectivity rather than the more scientific, and neoclassical, objectivity, like Tullock. 
Boettke (1987) took a similar view. From the introduction:

George Mason University provides a unique institutional environment for exploring the relationship between the "Virginia" or Public Choice school of political economy and Austrian economics. The strength of this relationship becomes particularly apparent if we consider the branch of public choice economics associated with James

Buchanan. The other branch of the Virginia school, which derives its research program mainly from Gordon Tullock, is, I would argue, more consistent with the neoclassical paradigm than the Austrian one... (Boettke, 1987, p7)

From this, not only do we see that Buchanan can be associated with the Austrians while Tullock is grouped with the neoclassicals, but also that there may be more than one branch of public choice, one for each school. This certainly could, then, lead to confusion as to how to classify Buchanan and public choice in general. Indeed, Boettke quotes Buchanan from his book Liberty, Market, and State:

I think it is accurate to say that my own emphasis was on modeling politics-as-exchange, under the acknowledged major influence of Knut Wicksell's great work in public finance. By comparison (and interestingly because he was not initially trained as an economist), Gordon Tullock's emphasis... was on modeling public choosers (voters, politicians, bureaucrats) in strict self-interest terms. There was a tension present as we worked through the analysis of that book, but a tension that has indeed served us well over the two decades since initial publication. (Buchanan, quoted by Boettke, 1987, p1)

Boettke stops short of saying that Buchanan is an Austrian, but he does suggest that he is a link between public choice theory and Austrian economics. First in the introduction where he says that Buchanan represents a relationship between the two, and then later he explains further: "By merging public choice insights with Austrian analysis - a framework in which Buchanan fits quite comfortably - Austrians can improve their understanding of political economy and buttress their case for individual liberty." (Boettke, 1987, p14)

Another writer who described a dichotomy within public choice was Fu-Lai Tony Yu. In the conclusion to his book, Yu (2011: pp 177-178) writes: 
Ever since founded by James Buchanan, the Public Choice School has developed into two streams: namely neoclassical Public Choice School and subjectivist Public Choice School. The former uses neoclassical optimization method to study the government, while the latter, in original Buchanan's flavor, understand the government in the subjectivist perspective.

Yu then goes on to explain how this "subjectivist perspective" is like the Austrians, particularly when it comes to Buchanan's view on cost, whereby he cites Cost and Choice, and with Buchanan's firm stance on methodological individualism, which is seemingly in contradiction to de Soto's view that methodological individualism falls under the purview of the neoclassicals.

The "AfterEcon" blog, moderated by George Mason University Economics PhD candidate John Vandivier, had a post entitled "James Buchanan and the Synthesis of Austrian and Neoclassical Economics." In it, he points to several links that could be drawn between Buchanan and neoclassicals like Ronald Coase. For example, Coase wrote his "Problem of Social Cost" paper while working in the Thomas Jefferson Center for Studies in Political Economy at the University of Virginia, while Buchanan was also working at the Center, which he helped create. Vandivier goes on to point out a similarity between public choice and Transaction Cost Economics (TCE), of which Coase was a major contributor:

Public Choice emphasizes the notion that political failure exists and therefore market failure may be preferred to political failure, so long as the market fails to a lesser degree than the political system. TCE also emphasizes this notion through the concept of remediableness. A market is considered efficient if there are no more efficient available coordination systems, even if the market produces an outcome less efficient than a competition-theoretic market would. (Vandivier, 2016)

Certainly, Buchanan is not a neoclassical based on the examples that Vandivier provides, and it isn't even clear how one can claim that either he or public choice theory in general represents a synthesis of Austrian and neoclassical economics. But it is noteworthy that, despite the neoclassical connections Vandivier claims to be present, Buchanan and public choice are also seen as connected to the Austrian school. 


\section{Conclusion}

There is enough explicit evidence that Buchanan was not a neoclassical economist. There is also ample evidence, as shown in this paper, that he should be considered an Austrian economist, with the caveat that the etymology of the term "Austrian economist" remains somewhat unsettled. Many of Buchanan's writings, particularly his two most prominent works (Calculus of Consent and Cost and Choice) lean heavily toward the Austrian school and away from the neoclassical approach. But is this enough to claim that Buchanan was, indeed, an Austrian? Some, like de Soto, seem to hold to a strict interpretation of what it means to be an Austrian. Supporters of this view might disqualify Buchanan because other public choice scholars are neoclassical, and following a backwards induction approach, Buchanan must be as well. Others, like Boettke, Baird, Yu, and perhaps even DiLorenzo, are more inclusive in their definitions. They don't all agree that Buchanan was an Austrian, but at a minimum they all see that his writings can fit comfortably within the Austrian canon.

The notion of inclusiveness is what it seems the question comes down to - how narrow or broad one defines Austrian economics. Yaeger (2014) makes this very point in addressing a possible Austrian connection to Buchanan's work: Here the question is how narrow or how broad a meaning to give to 'Austrian economist'... But on a quite inclusive interpretation of 'Austrian economist', Buchanan might count as one." Even Yaeger seems conflicted, however, as he goes on to point out that the only two economists Buchanan ever gave credit to for influencing his work were Knight and Wicksell. Not even in his Nobel acceptance speech, given for his work in public choice, did he mention any Austrian influence.

Over time, heterodox schools such as the Austrian school seem to be accepted more and more by the mainstream. But they are still viewed as outsiders. Mainstream economists tend to dismiss Austrian works due to, among other things, the lack of rigorous empirical proofs. But part of the blame can be placed on Austrians themselves. As Buchanan (1979: pp 83-84) explains: "It seems to me that one of the dangers of the subjectivist approach, and particularly in its pure Austrian variant, is the tendency to form a priesthood, with the converted talking only to those who are converts, and with the deliberate withdrawal from free and open espousal of subjectivist notions to the world around." It is along similar lines that strict adherence to an inelastic definition of "Austrian economics" such as has been discussed above fosters the very dismissiveness that some Austrians might denounce as elitist or out-of-touch. Being more inclusive in their grouping would 
certainly lead to growth within the field. As was pointed out by Boettke (1987, p14), Austrians can gain a great deal from Buchanan and public choice theory.

Assigning labels retroactively can often lead to disagreement. Nevertheless, it is a somewhat common occurrence in fields such as History of Economic Thought, and the field is all the better for it. Such debate can seem irrelevant at times and one could argue that the participants lose the focus of the economic works while needlessly trying to affix some classification to the economist. But, to borrow from Buchanan and his letter to the Mont Pelerin Society members, "....survival of the time-honored ideals of the free society can be achieved only through a continuously critical examination..." of said ideals. Debates such as this over schools of thought represent that continuous critical examination Buchanan spoke of. Through continued appreciation, examination, and introspection, the field of economics can mature and progress forward. Which is what Buchanan was calling on his fellow economists to do. 


\section{References}

Baird, C. W., 1989. "James Buchanan and the Austrians: The Common Ground." Cato Journal, vol 9, no 1 , pp. 201-230.

Boettke, P. J., 1987. "Virginia Political Economy: A View from Vienna." Market Process, vol 5, no 2, pp. 7-15.

Boettke, P. J., 1998. "James M. Buchanan and the Rebirth of Political Economy." In: R. P. Holt \& S. Pressman, eds. Economics and its Discontents: Twentieth Century Dissenting Economists.

Cheltenham: Edward Elgar Publishing Limited, pp. 21-39.

Boettke, P. J., 2008. "Austrian School of Economics." The Concise Encyclopedia of Economics [Online] Available at: http://www.econlib.org/library/Enc/AustrianSchoolofEconomics.html

[Accessed 16 August 2017].

Buchanan, J. M., 1964. "What Should Economists Do?" Southern Economic Journal, vol 30, no 3, pp. 213-222.

Buchanan, J. M., 1969. Cost and Choice: An Inquiry in Economic Theory. Chicago: University of Chicago Press.

Buchanan, J. M., 1978. "From Private Preferences to Public Philosophy: The Development of Public Choice." In: The Economics of Politics. London: The Institute of Economic Affairs, pp. 1-20.

Buchanan, J. M., 1979. What Should Economists Do?. Indianapolis: Liberty Fund, Inc..

Buchanan, J. M., 1984. "Politics without Romance: A Sketch of Positive Public Choice Theory and Its Normative Implications." In: J. M. Buchanan \& R. D. Tollison, eds. The Theory of Public Choice II. Ann Arbor: The University of Michigan Press, pp. 11-22.

Buchanan, J. M., 2007. Economics From the Outside In. College Station: Texas A\&M University Press.

Buchanan, J. M., 2012. "Genesis." Public Choice, vol 152, no 3/4, pp. 253-255.

Christainsen, G. B., 1988. "James Buchanan and the Revival of Classical Political Economy."

Challenge, vol 31, no 2, pp. 11-15.

Chwe, M., 2017. "The beliefs of economist James Buchanan conflict with basic democratic norms. Here's Why." The Washington Post [Online]

Available at: https://www.washingtonpost.com/news/monkey-cage/wp/2017/07/25/the-beliefs-ofeconomist-james-buchanan-conflict-with-basic-democratic-norms-heres-

why/?utm term $=$. .a553c513823a

[Accessed 29 July 2017].

de Soto, J. H., 1998. "The Ongoing Methodenstreit of The Austrian School." Journal des Economistes et des Etudes Humaines, vol 8, no 1, pp. 75-113.

de Soto, J. H., 2010. Socialism, Economic Calculation and Entrepreneurship. Cheltenham: Edward Elgar.

DiLorenzo, T. J., 1988. "Competition and Political Entrepreneurship: Austrian Insights into Public Choice Theory." Review of Austrian Economics, vol 2, no 1, pp. 59-71. 
DiLorenzo, T. J., 1990. "The Subjectivist Roots of James Buchanan's Economics." The Review of Austrian Economics, vol 4, no 1, pp. 180-195.

Formaini, R. L., 2003. "James M. Buchanan - The Creation of Public Choice Theory." Economic Insights, vol 8, no 2.

Formaini, R. L., 2004. "Knut Wicksell" - The Birth of Modern Monetary Policy. Economic Insights, vol 9 , no 1.

Hartley, K., 2000. "Jack Wiseman, 1919-1991." The Economic Journal, vol 110, no 464, pp. F445-F454.

Henderson, D. R., 2007. "Frank Hyneman Knight (1885-1972)." The Concise Encyclopedia of

Economics [Online]

Available at: http://www.econlib.org/library/Enc/bios/Knight.html

[Accessed 13 September 2017].

Kirzner, I. M., 1965. "What Economists Do." Southern Economic Journal, vol 31, no 3, pp. 257-261.

Kirzner, I. M., 2008. "Austrian economics." The New Palgrave Dictionary of Economics, Second Edition, Edited by Steven N. Durlauf and Lawrence E. Blume.

Klein, P. G., 2016. Frank Knight and the Austrians. [Online]

Available at: https://mises.org/blog/frank-knight-and-austrians

[Accessed 13 September 2017].

Northwood University, 2010. Austrian Economics versus the Mainstream: An Interview with Richard M. Ebeling. [Online]

Available at: http://defenseofcapitalism.blogspot.com/2010/11/austrian-economics-versusmainstream.html

[Accessed 13 September 2017].

Rizzo, M. J., 2014. "James M. Buchanan: Through an Austrian window." Review of Austrian Economics, vol 27, no 2, pp. 135-145.

Robbins, L., 1932. In: An Essay on the Nature and Significance of Economic Science. London: Macmillan and Co., Limited, p. 15.

Steelman, A., 2004. Full Interview with James Buchanan. [Online]

Available at:

https://www.richmondfed.org/publications/research/region focus/2004/spring/full interview [Accessed 31 May 2017].

Thornton, M. \& Thommesen, S., 1987. "An Interview with Nobel Laureate James Buchanan." Austrian Economics Newsletter, Fall, pp. 3-4.

Vanberg, G., 2017. "Was Nobel Laureate James Buchanan really opposed to democracy? Not at all." The Washington Post [Online]

Available at: https://www.washingtonpost.com/news/monkey-cage/wp/2017/08/04/iames-

buchanan-was-committed-to-basic-democratic-values/?utm term=.5f683d6d043b

[Accessed 10 August 2017]. 
Vandivier, J., 2016. James Buchanan and the Synthesis of Austrian and Neoclassical Economics. [Online]

Available at: http://www.afterecon.com/economics-and-finance/iames-buchanan-and-thesynthesis-of-austrian-and-neoclassical-economics/

[Accessed 5 June 2017].

Voltaire, 1843. A Philosophical Dictionary. London: W. Dugdale.

Weintraub, E. R., 2002. "Neoclassical Economics." The Concise Encyclopedia of Economics [Online] Available at: http://www.econlib.org/library/Enc1/NeoclassicalEconomics.html

[Accessed 16 August 2017].

Yeager, L. B., 2014. "Reminiscences of James Buchanan and the Virginia School." Review of Austrian Economics, vol 27, no 2, pp. 165-173.

Yu, F.-L. T., 2011. New Perspectives on Economic Development: A Human Agency Approach. The Netherlands: Wageningen Academic Publishers. 